\title{
The Goose
}

Volume 13 | No. 1

Article 35

8-14-2014

\section{Guddling About: Experiments in Vital Materialism with Particular Regard to Water}

\author{
Minty Donald \\ University of Glasgow
}

Part of the Art Practice Commons, Critical and Cultural Studies Commons, Nature and Society Relations Commons, Performance Studies Commons, and the Place and Environment Commons Follow this and additional works at / Suivez-nous ainsi que d'autres travaux et œuvres: https://scholars.wlu.ca/thegoose

\section{Recommended Citation / Citation recommandée}

Donald, Minty. "Guddling About: Experiments in Vital Materialism with Particular Regard to Water." The Goose, vol. 13 , no. 1 , article 35,2014 ,

https://scholars.wlu.ca/thegoose/vol13/iss1/35.

This article is brought to you for free and open access by Scholars Commons @ Laurier. It has been accepted for inclusion in The Goose by an authorized editor of Scholars Commons @ Laurier. For more information, please contact scholarscommons@wlu.ca.

Cet article vous est accessible gratuitement et en libre accès grâce à Scholars Commons @ Laurier. Le texte a été approuvé pour faire partie intégrante de la revue The Goose par un rédacteur autorisé de Scholars Commons @ Laurier. Pour de plus amples informations, contactez 


\section{MINTY DONALD}

\section{Guddling About: Experiments in Vital Materialism with Particular Regard to Water}

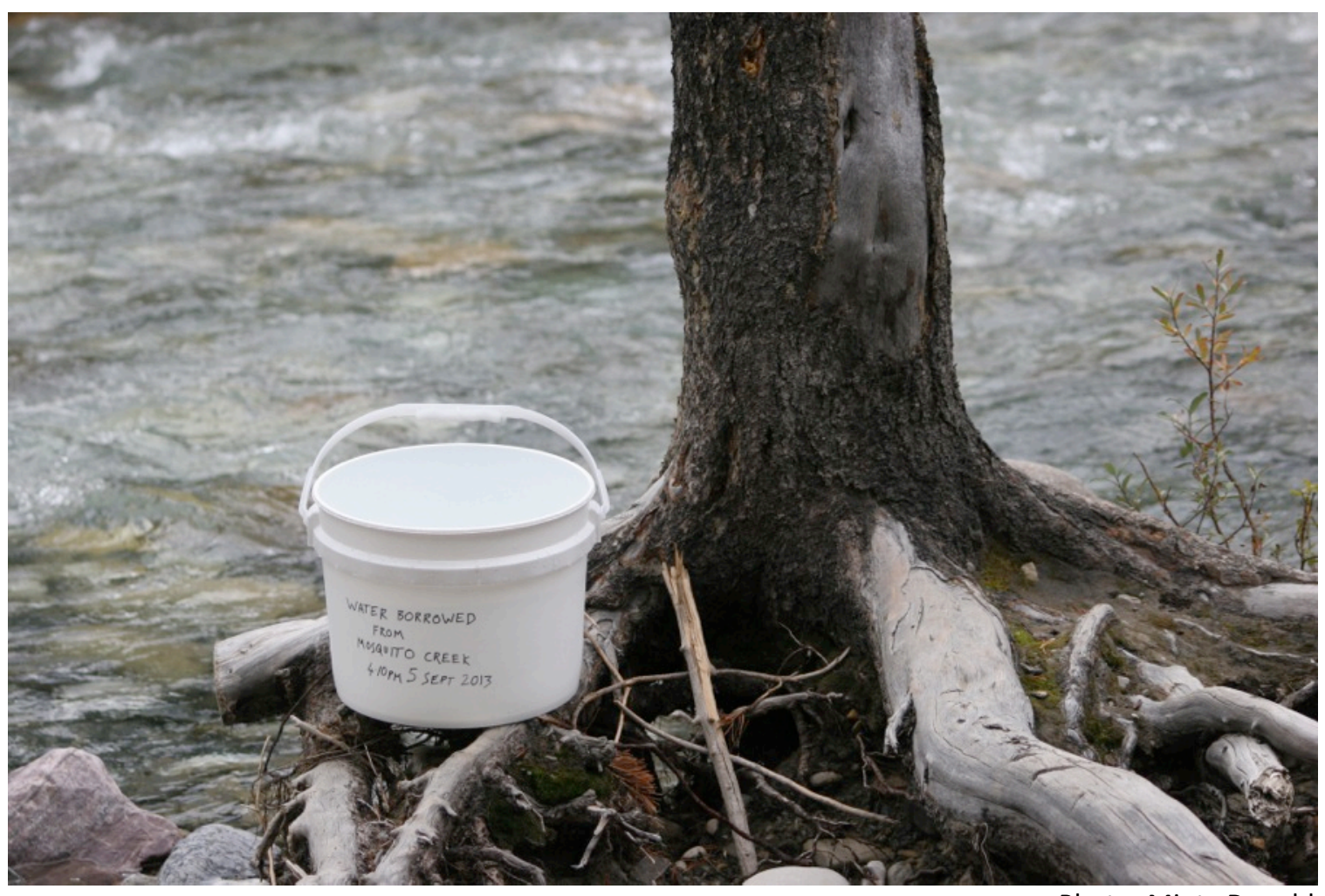

Photo: Minty Donald

\section{Introduction}

In April 2013 I travelled with my partner and regular collaborator, Nick Millar, from our home city, Glasgow, Scotland to undertake the first phase of a three-month artists' residency in Calgary, Alberta, hosted by Watershed+ (http://www.watershedplus.ca). The residency programme was attached to two City of Calgary Departments: Utilities and Environmental Protection (Water Services) and Public Art. Its intention was to offer artists "a unique opportunity to explore, experiment and engage in thoughts and conversations around Calgary's Watershed [...and] water management, resulting in an enriched understanding of contemporary artistic practice and the environment - for artists, the public and the City of Calgary staff" (Watershed+). For us, the residency was a timely and 
invaluable chance to extend and develop our ecological practice, which explores human/environment interdependencies in specific geographical and cultural contexts, and which has most recently focused on human/water interrelations examined through a series of site-specific performances and events devised with, for, and about the River Clyde - the major watercourse that flows through Glasgow city center.

During a presentation to City of Calgary Public Art staff in April 2013, I unthinkingly used the word "guddling," well-known in Scotland but foreign to our audience in Calgary. ${ }^{1}$ At the end of the presentation an audience member remarked on the word. "I'd never heard it before," she said, "but it sounds like the noise of a creek or of water when you run your hand through it. I kind of knew what it meant." Unwittingly, I had hit on a fitting title for our work in Calgary, and an evocative description of our practice. "Guddling," alongside its watery connotations, suggests the playful, sensorial, and experimental approach that we adopt in our work. To guddle is to act without clear purpose, to feel or grope one's way, but to do so through sensory and tactile engagement with the physical environment. It has strong associations with childlike or playful activity (I can hear my Mum's voice: "Can you stop guddling about, Minty? It's time for school."). But it also, in its onomatopoeia, invokes the sound of water, giving "voice" to the non-human (or, as we prefer, more-than-human) participants in our work.

A concern with giving "voice" to the more-than-human, acknowledging its liveliness and potential agency, is central to our practice. In the course of our work with the Clyde, we have become increasingly interested in considering the kinds of agency and life-force that might be attributed to more-than-human entities, such as water or rivers. Jane Bennett, in her book Vibrant Matter, speculates on the consequences of entertaining seriously the idea of more-than-human vitality, particularly regarding human perspectives on what we commonly refer to as "the environment." She considers what might be at stake if we perceived all matter (human, animal, mineral...) to have an inherent liveliness. While we, as humans, may not be able to comprehend the nature of the vitality of more-thanhuman stuff, she argues that we should strive to develop tactics that allow us to discern and attend to this vitality. In doing so, we might radically shift our perceptions of and attitudes towards the more-than-human, challenging our anthropocentric assumptions and altering the way we think about our place in the world. Bennett argues that this could bring about a productive shift from considering ourselves as stewards of the environment - as humans responsible for the care of the more-than-human - to seeing ourselves as part of a vibrant ever-evolving web of interconnected matter.

Our intention on the residency was to carry out a series of experiments, actions, or performances, devised to encourage us and others to consider, seriously but playfully, water as an active agent, a more-than-human force with which all other human and morethan-human entities are interdependent. Guddling About was initially designed with and

\footnotetext{
${ }^{1}$ Guddling: Verb. Scots. To mess about. To catch fish by hand groping under stones and riverbanks where they lurk.
} 
for the Bow River and its watershed in the City of Calgary and Southern Alberta in the spring and summer of 2013. We will be repeating some of the experiments, and developing some new ones, with the River Clyde in the City of Glasgow and elsewhere in Scotland from June to September 2014, with financial support from Creative Scotland. ${ }^{2}$ Each action, experiment, or performance is described as a set of instructions - or, if you like, a script or score for an event - which can be enacted by anyone in any location where human settlement has evolved around a river.

This photo-essay documents four of the experiments with water and rivers that we undertook in Canada. It reflects on some of the questions the actions raised regarding human relationships with water in the context of Calgary, and speculates on what other questions and issues might arise from carrying out the actions in Glasgow.

\section{Guddling About}

A series of experiments, actions, or performances with water...

- To be carried out with any river around which human settlement has developed.

- Inviting contemplation on the interdependency between humans and water.

- Engaging with the specificities of different fluvial locations, while recognising their shared identities as modified waterways.

- Where water (and other more-than-human entities) performs alongside human actors and determines some of the parameters and qualities of each event.

\section{Context: The Bow River, Calgary and the River Clyde, Glasgow}

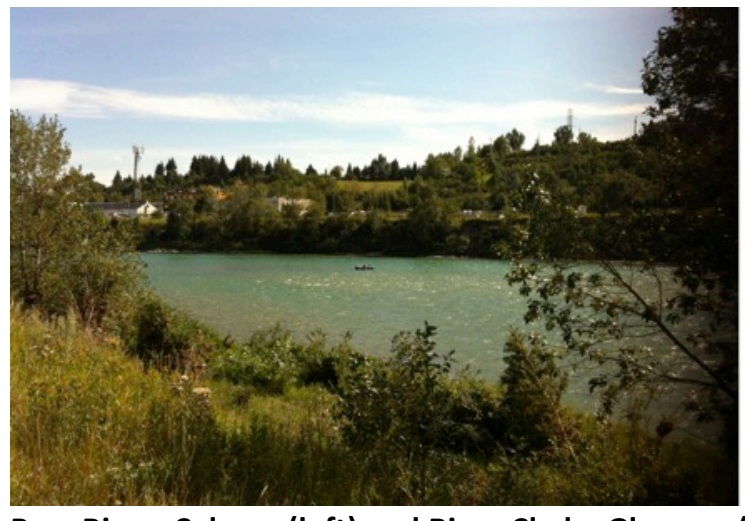

Bow River, Calgary (left) and River Clyde, Glasgow (right)

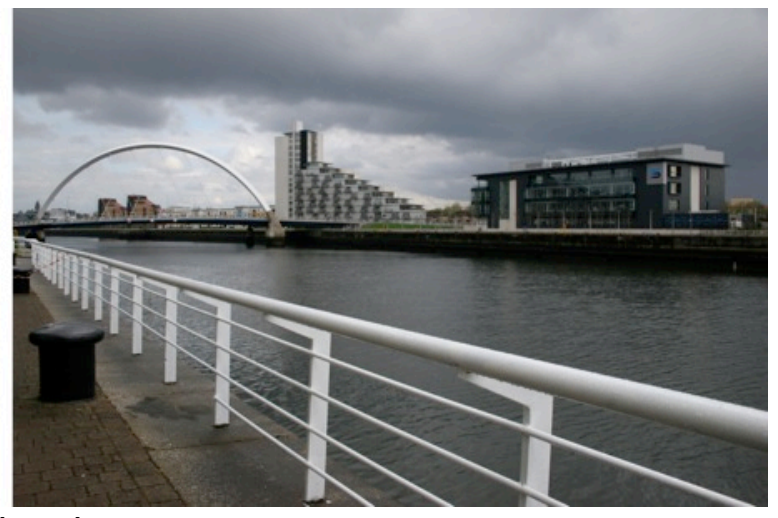

Photos: Minty Donald

The major waterways that flow through Calgary and Glasgow are, at first glance, very different in character. Their physical appearances are dissimilar, they play different functional and symbolic roles within the two cities, and they each have their own singular

\footnotetext{
${ }^{2}$ Visit Creative Scotland's website at http://www.creativescotland.com.
} 
histories of human intervention and development.

The Bow River and its watershed provide drinking water for Calgary and much of Southern Alberta. The Bow is an iconic Canadian River featured in Otto Preminger's film River of No Return (1954). It emerges from the Bow Glacier and Bow Lake in the Rocky Mountains and is a site of recreation and contemplation for Calgarians. However, in June 2013, it flooded severely, submerging downtown Calgary and damaging irrevocably a significant proportion of property in the city centre. ${ }^{3}$

The River Clyde in Glasgow is a heavily modified watercourse, which was narrowed, deepened, and embanked to enable trade, shipbuilding, and large-scale manufacturing in Glasgow from the early-19th to mid-20th centuries. There is a, now-well-worn, Glaswegian saying: "The Clyde Made Glasgow and Glasgow Made the Clyde," which encapsulates a prevalent attitude towards the industrialised river during this period. Since the decline of heavy industry in Glasgow in the 1960s and 70s, however, the Clyde's status in the city has become ambivalent. Despite major regeneration currently underway on its banks, the watercourse itself remains largely neglected and significantly polluted. The city seems unsure what to do with, or how to relate to, this body of water that has been subject to such major human intervention.

3 Our three-month residency was split between April 2013 and August-September 2013 - that is, pre- and post-flood. On our return to post-flood Calgary, we gave serious consideration to the appropriateness and sensitivity of our plan to conduct a series of "playful" experiments, intended to encourage us and others to engage with water as an active agent, a more-than-human force with which all other human and more-thanhuman entities are interdependent. We considered a more direct address to the flood but judged that, as outsiders with no first-hand experience of the June 2013 events, this might feel opportunistic and insensitive. We ultimately decided that the actions/experiments we had initially envisaged might resonate in relatively quiet but thought-provoking ways with some of the feelings and issues evoked by the flood - by the forceful display of water's liveliness and willfulness witnessed in Southern Alberta in June 2013. 


\section{Guddling About: Calgary}

\section{Experiment \#1: Water Carry}

Scoop water from the river with bare, cupped hands. Carry the water in your hands as far as possible from the river. Stop when there is no water left in your hands.
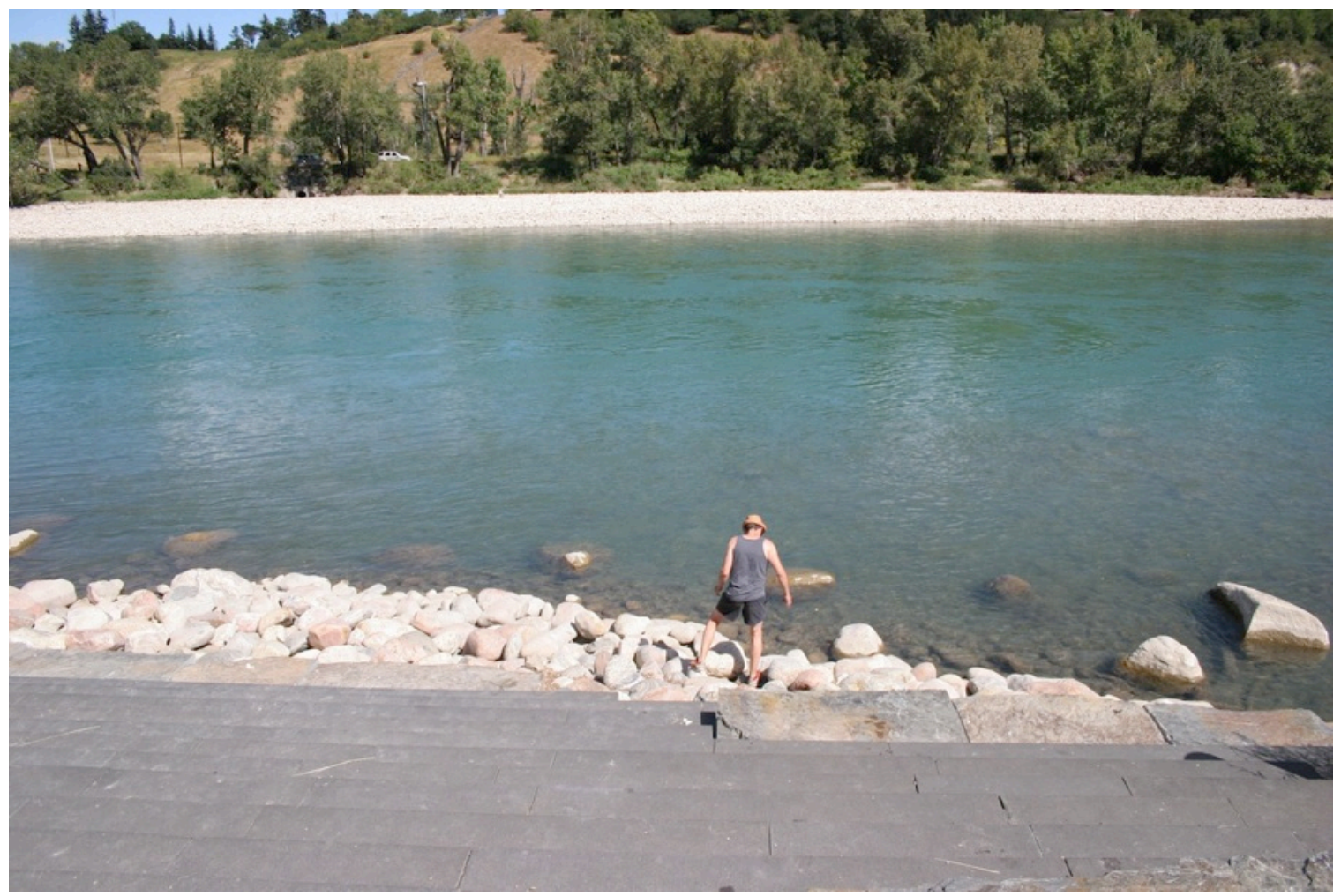

Nick Millar, Water Carry, Calgary, August 2013

Photo: Minty Donald

We looked for places where we could reach the river's edge and where we could crouch to gather water in our hands.

We were struck by the deep blue-green colour of the river.

We noticed the silt mingled with the water as we scooped it up.

We felt the warmth of the shallow water heated by the sun.

We sensed the surge as we placed our hands within the flow.

We felt the water smooth and soft on our hands. 


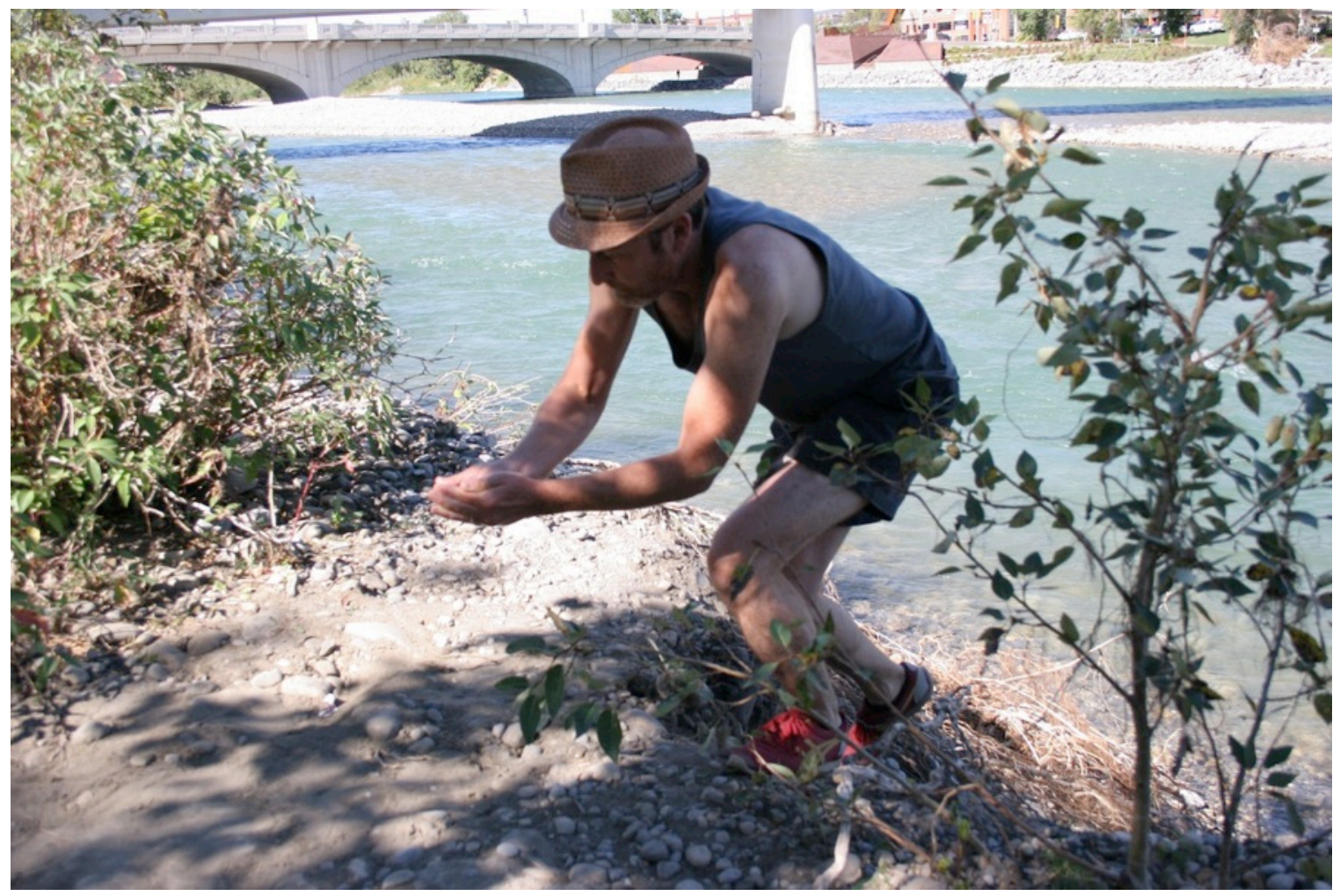

Nick Millar, Water Carry, Calgary, August 2013

Photo: Minty Donald

We strained our muscles to stand while keeping the water cupped in our hands.

We struggled to keep our balance as we walked up the steep, stony riverbank. 


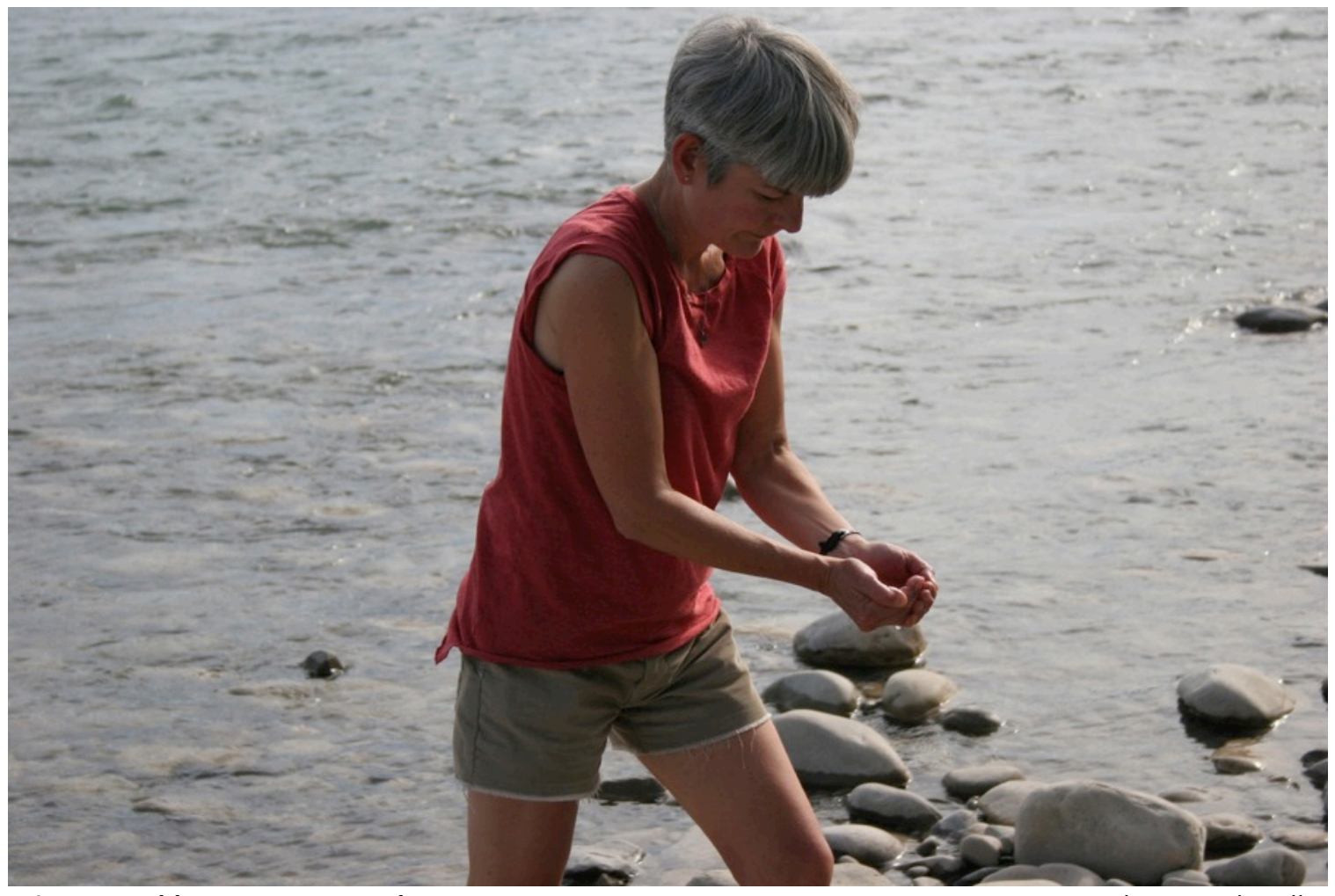

Minty Donald, Water Carry, Calgary, August 2013

Photo: Nick Millar

We thought about the mass of water moulded in our hands, and how it was constantly changing and diminishing.

We felt our hands cramping as we strove to stop the water from seeping between our fingers.

We noticed how quickly the water drained at first and then how long the last few drops took to filter through our fingers. 


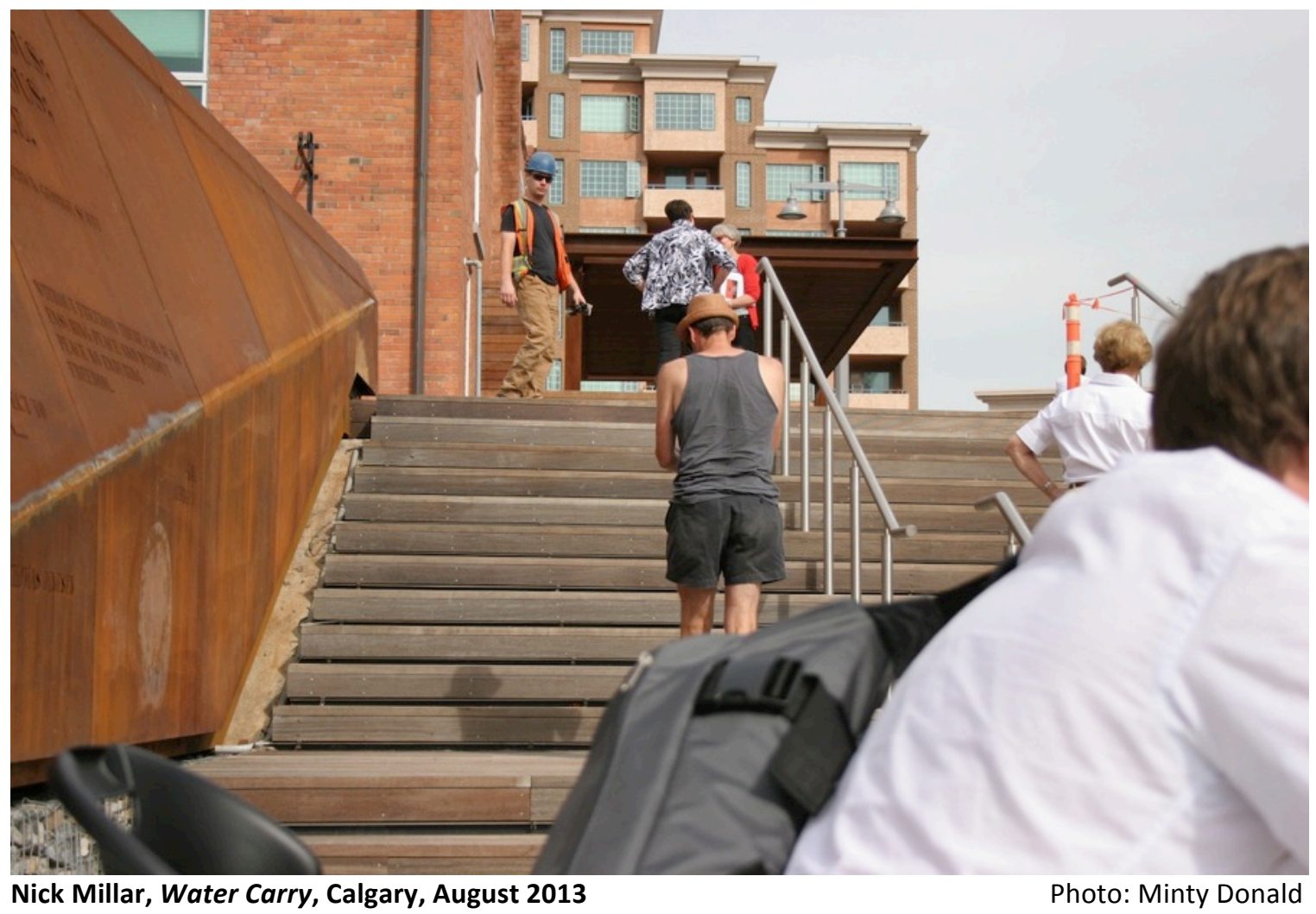

We kept one eye on the water in our hands and one on the terrain we were navigating. We felt the eyes of people on us as they glanced, or stared, at what we were doing. We tried to keep moving and to avoid the traffic. 


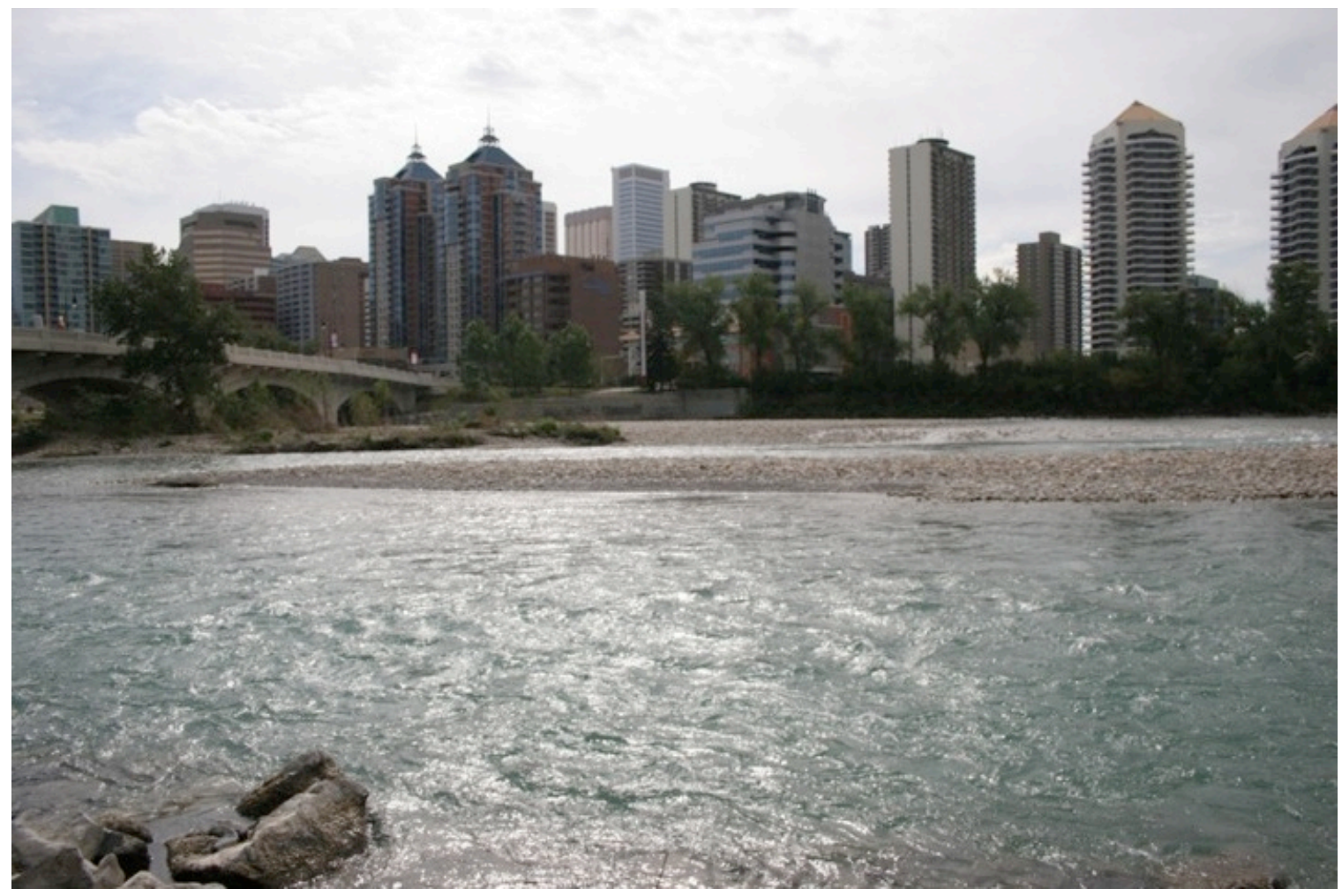

Bow River, Calgary, August 2013

Photo: Minty Donald

We thought about the non-human animals that might come to drink at the river.

We thought about how early settlers by the river might have filled bowls, buckets, and bottles with water for their own use.

We noticed signs of people living rough by the river, taking up seasonal residence in the undeveloped riparian land between the water's edge and the city. 

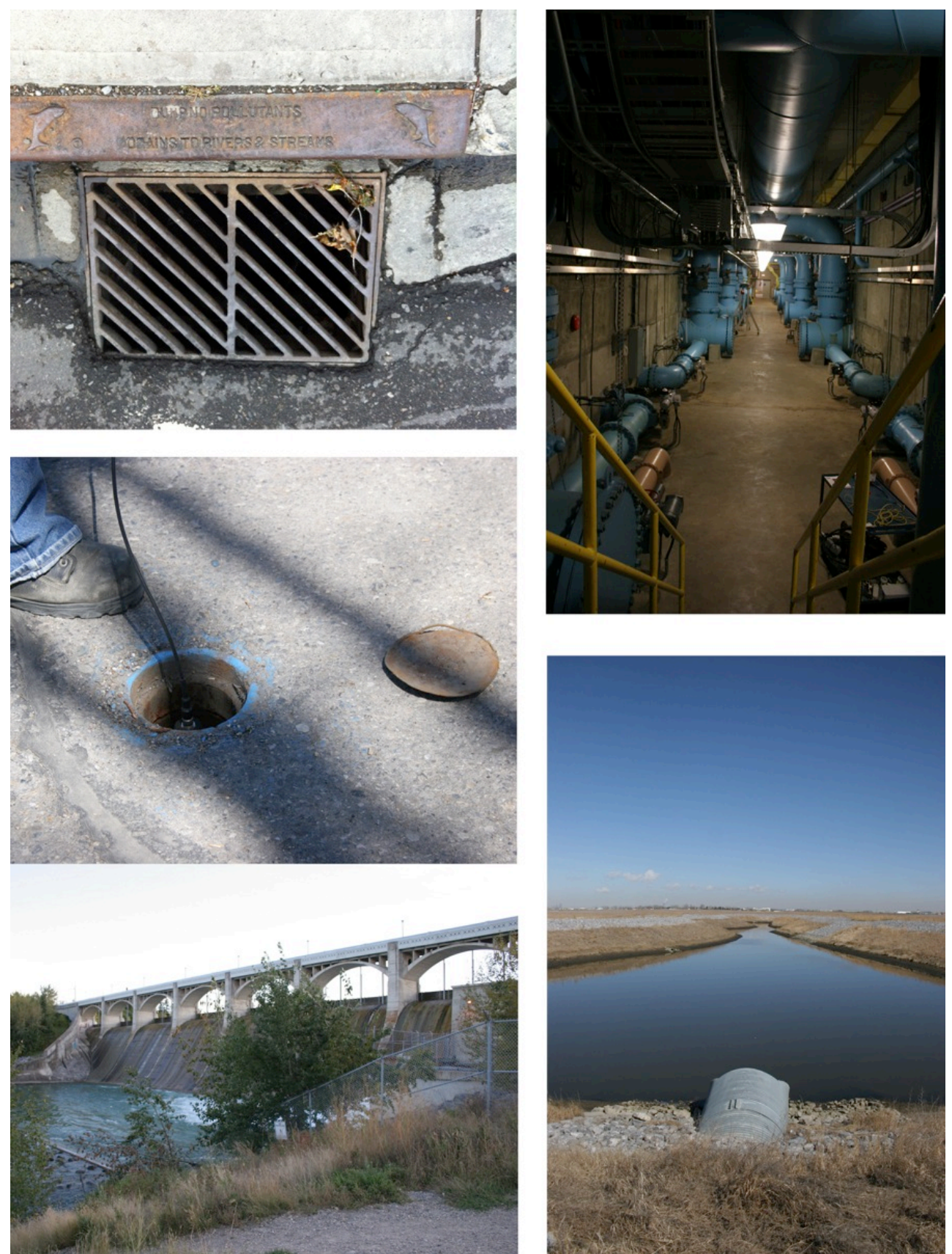

Clockwise from top left: Storm water drains; water treatment plant; Ralph Klein Park water treatment wetland; Glenmore Dam; testing for leaks in drinking water pipes

Photos: Minty Donald

We thought about the storm water drains that feed into the river.

We thought about the infrastructure of pipes, dams, and reservoirs that channel and control the water moving through the city.

And we thought about the storm water ponds and purifying plants where water is treated for human consumption. 


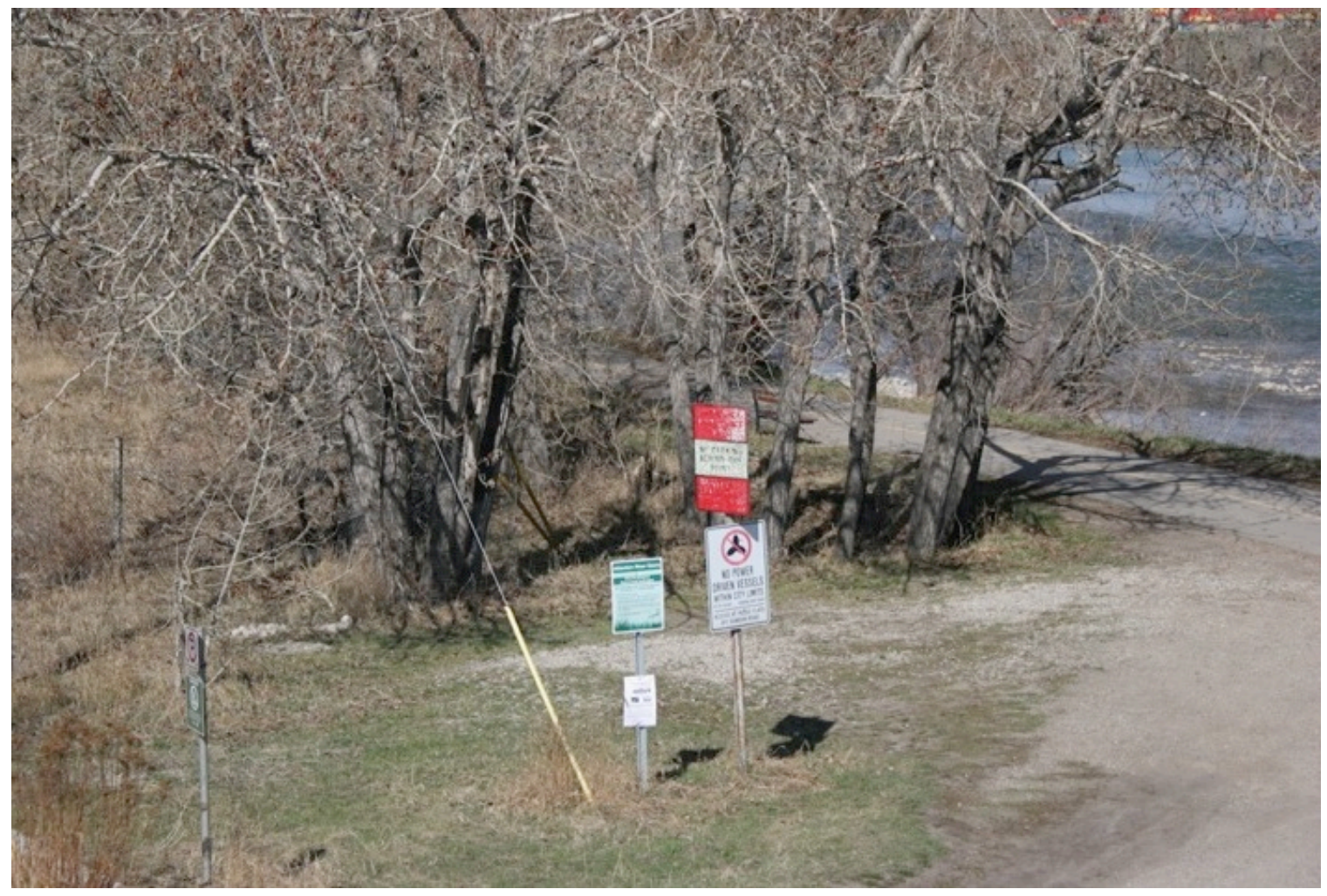

Bow River, Alberta, August 2013

Photo: Minty Donald

We thought about the laws that regulate how much water can be taken from the riverand that we might be breaking those laws. 


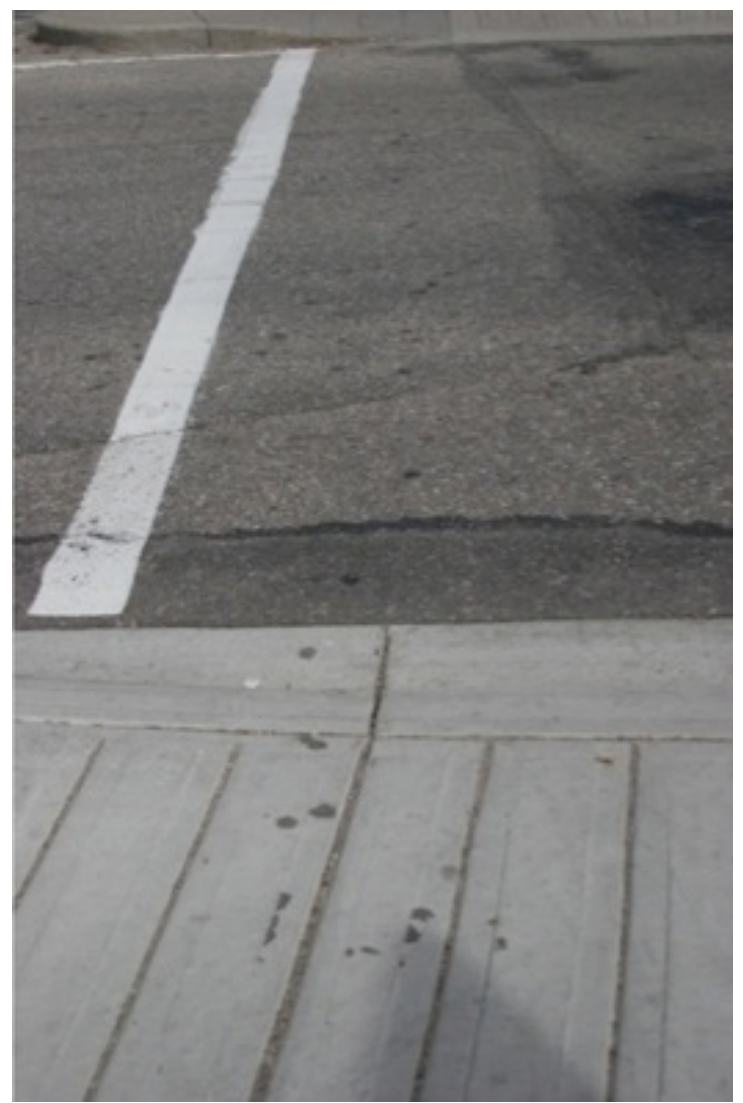

Water drips, Water Carry, August 2013

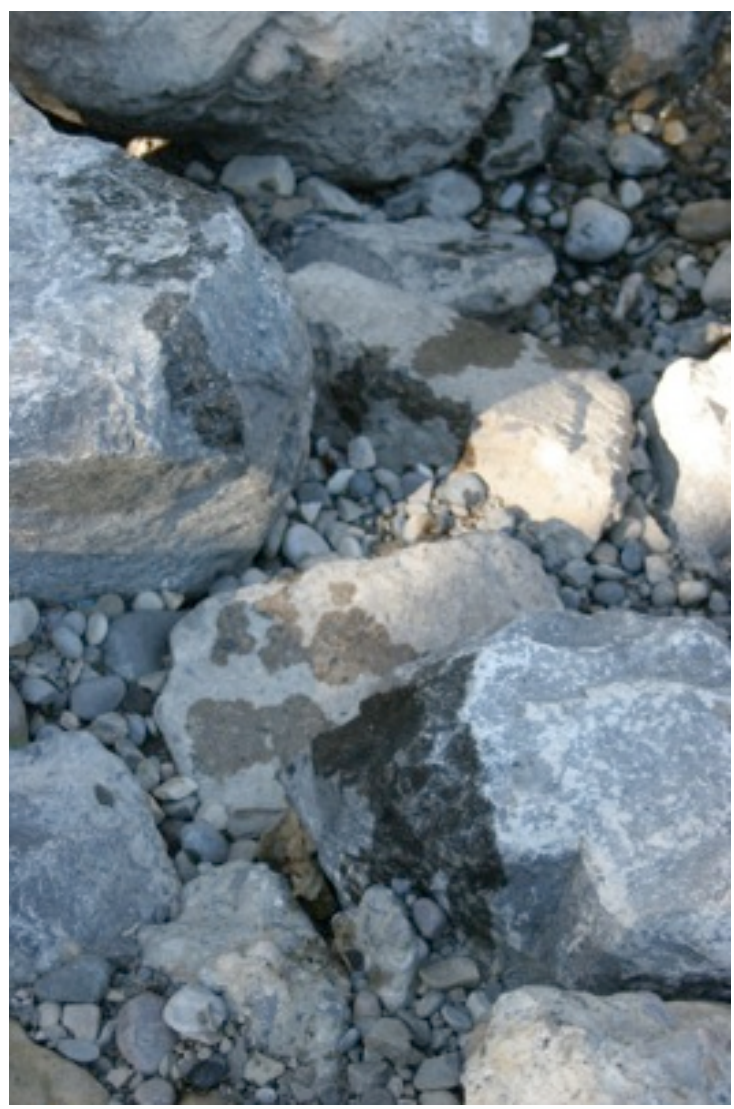

Photos: Minty Donald

We noticed the trails of drips on the ground that left a trace of our journey with the water. We thought they reminded us of scores, scripts, or maps that the water had marked on the ground.

We noticed how quickly the droplets evaporated, disappearing in the hot sun.

We noticed where the water seeped immediately into the earth and where it gathered in small puddles. 


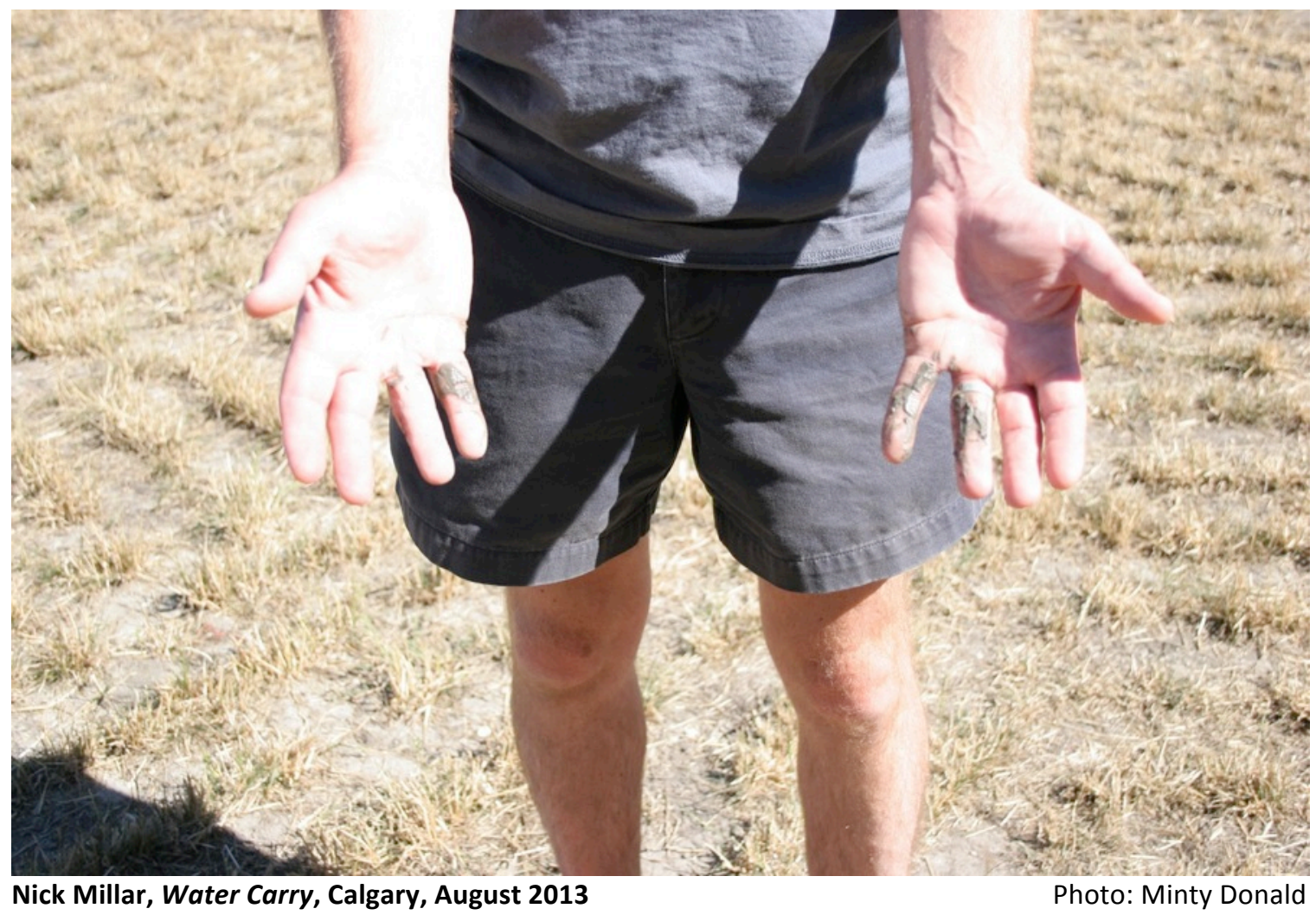

We felt the skin of our hands polished and desiccated by the mineral residues from the water. 


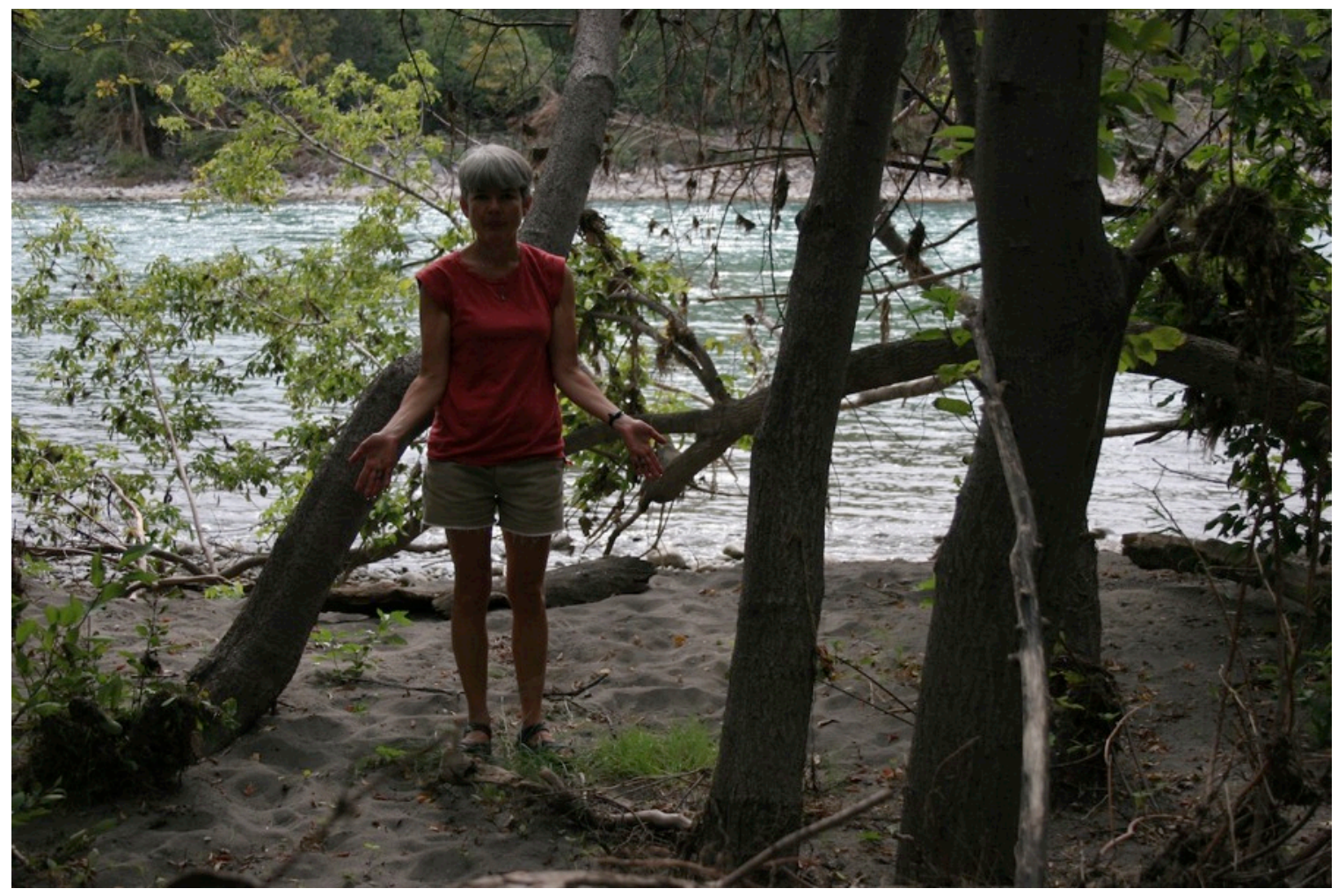

Minty Donald, Water Carry, Calgary, August 2013

Photo: Nick Millar

We tried to carry the water as far as we could.

We felt disappointed when it escaped after a few steps. 


\section{Experiment \#2: Water Borrow}

Visit as many tributaries of the river as possible. Ask each tributary you visit for permission to borrow some water. If you feel permission has been granted, carefully take a pailful of water, noting the date, time, weather conditions, topographical features, and water quality. Remember to thank each tributary for the water.

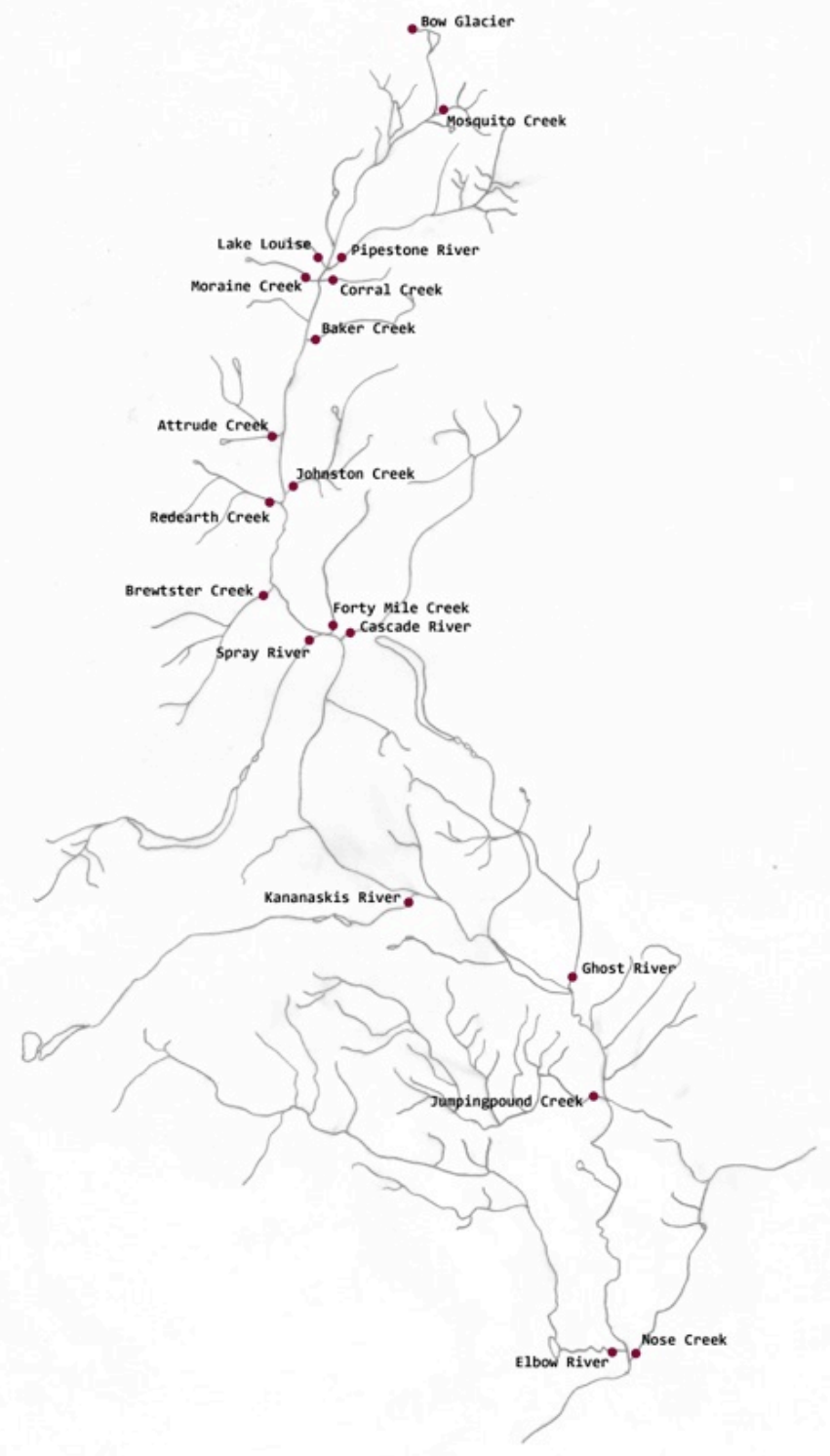

Bow River tributaries, Southern Alberta

Image: Minty Donald

We identified as many tributaries as we could reach by road and foot between Calgary and the source of the Bow River at Bow Glacier in the Rocky Mountains. 


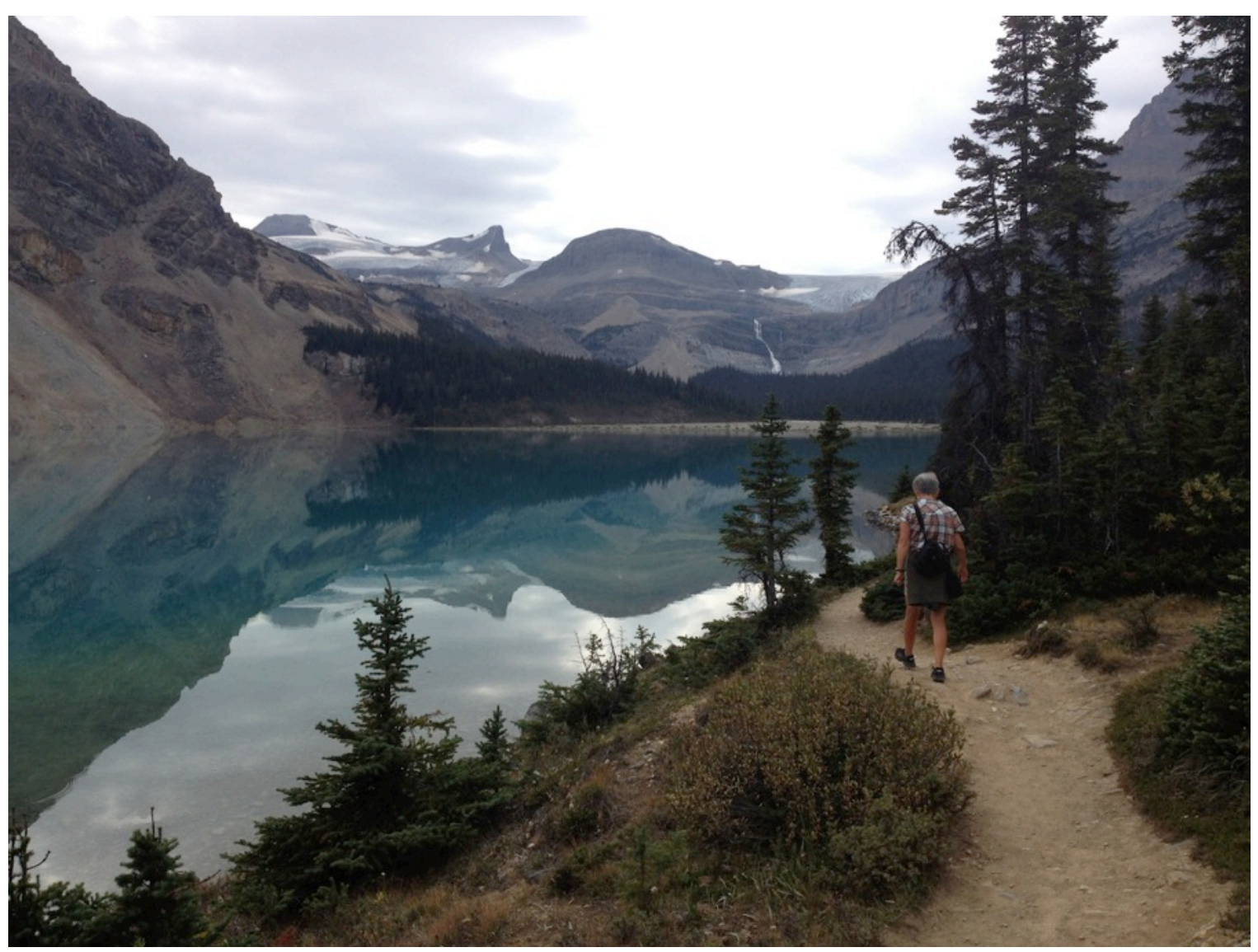

Minty Donald, Bow Lake, Alberta, August 2013

Photo: Nick Millar

We drove to Bow Lake, near Bow Glacier, stopping where we could get access to the rivers and creeks that feed into the Bow. 


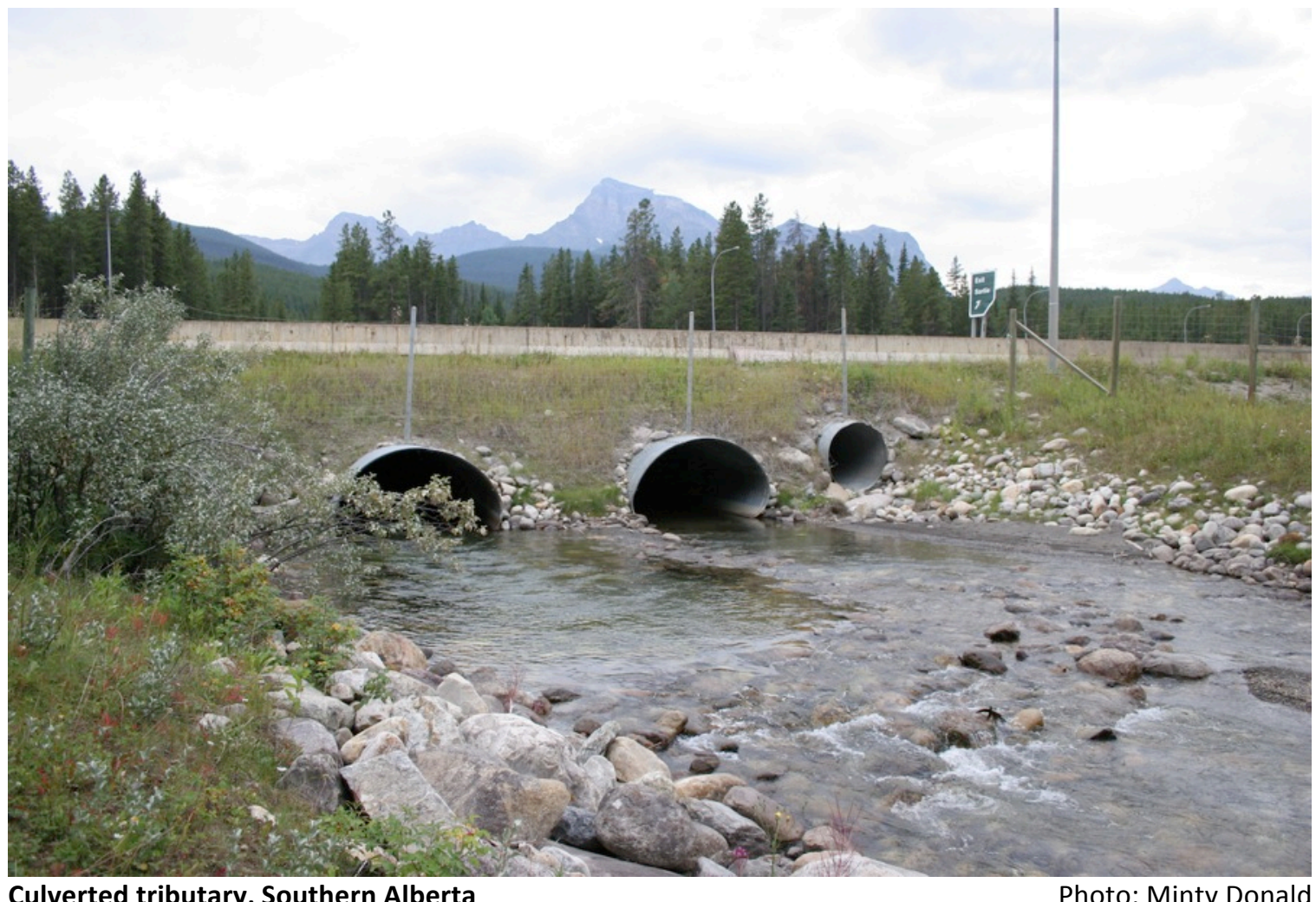

We noticed how the rivers and creeks had been bridged and culverted to allow the highway to pass over them.

We saw other signs of humans intervening to alter the rivers' behaviour - diverting their courses, controlling the volume and speed of their flow, harnessing their force to serve human demands. 


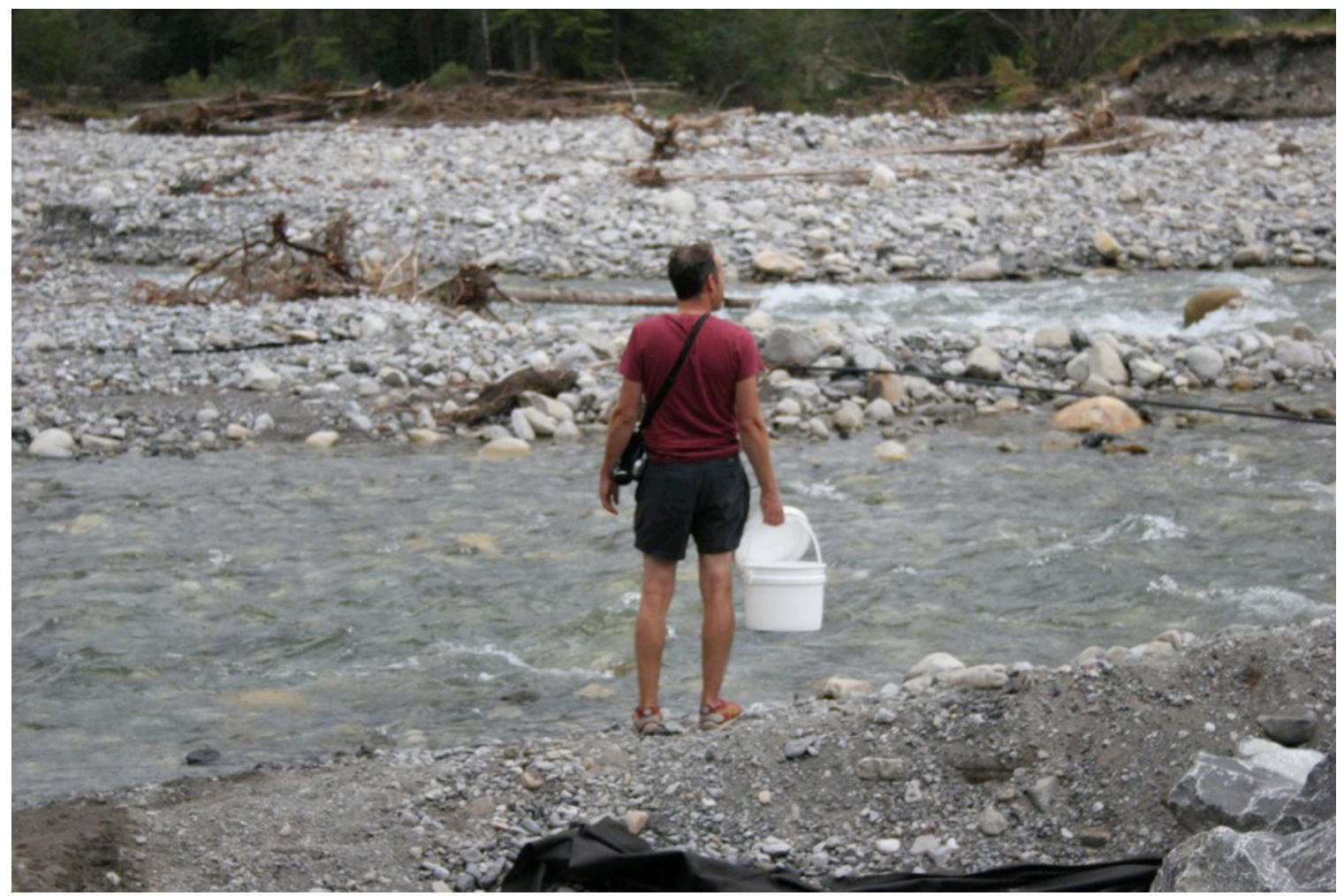

Nick Millar asking Pipestone River for permission to borrow water

Photo: Minty Donald

We asked each river or creek for permission to borrow a pailful of its water.

We felt slightly foolish standing by the rivers' edge, talking to the water.

We waited for a moment, listening to the sounds of the running water.

We noticed the variation in the tone, pitch, and quality of the noises of the different tributaries.

We realised the futility of attempting to communicate with rivers - the impossibility of humans conversing with or understanding the more-than-human.

But we felt that at least we had made a gesture. 


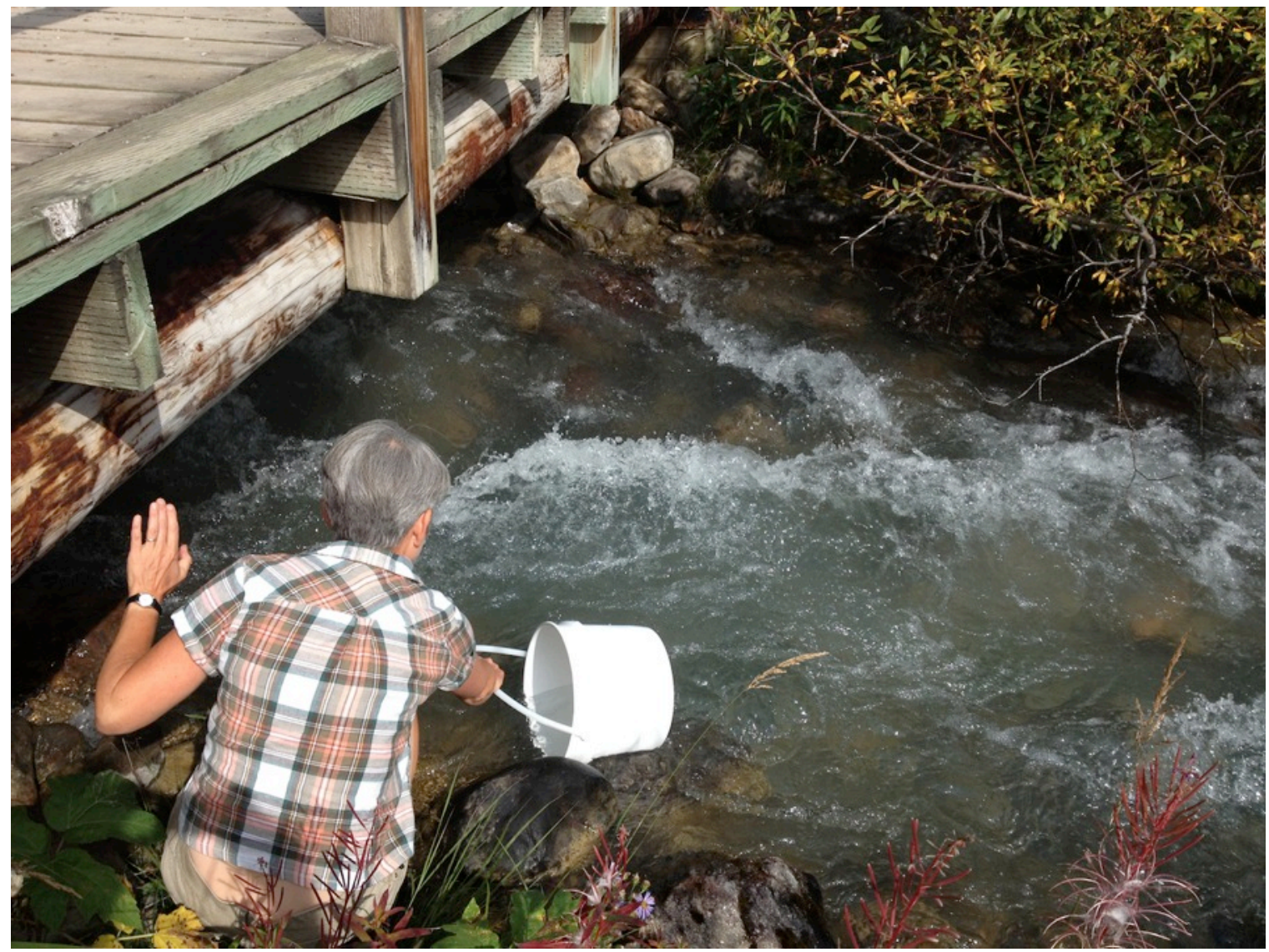

Minty Donald borrowing water from Lake Louise

Photo: Nick Millar

We placed our buckets in the water, taking care not to disturb the riverbed.

We felt the force of the water pushing against the white plastic pail that constrained it. We felt the weight of the water as we lifted the half-full buckets from the stream.

We noticed the variation in the colour of the water in our buckets, tinted by the mineral residues of the terrain it flowed through, or from waste draining into the water. We thanked each river or creek for the water we had borrowed. 


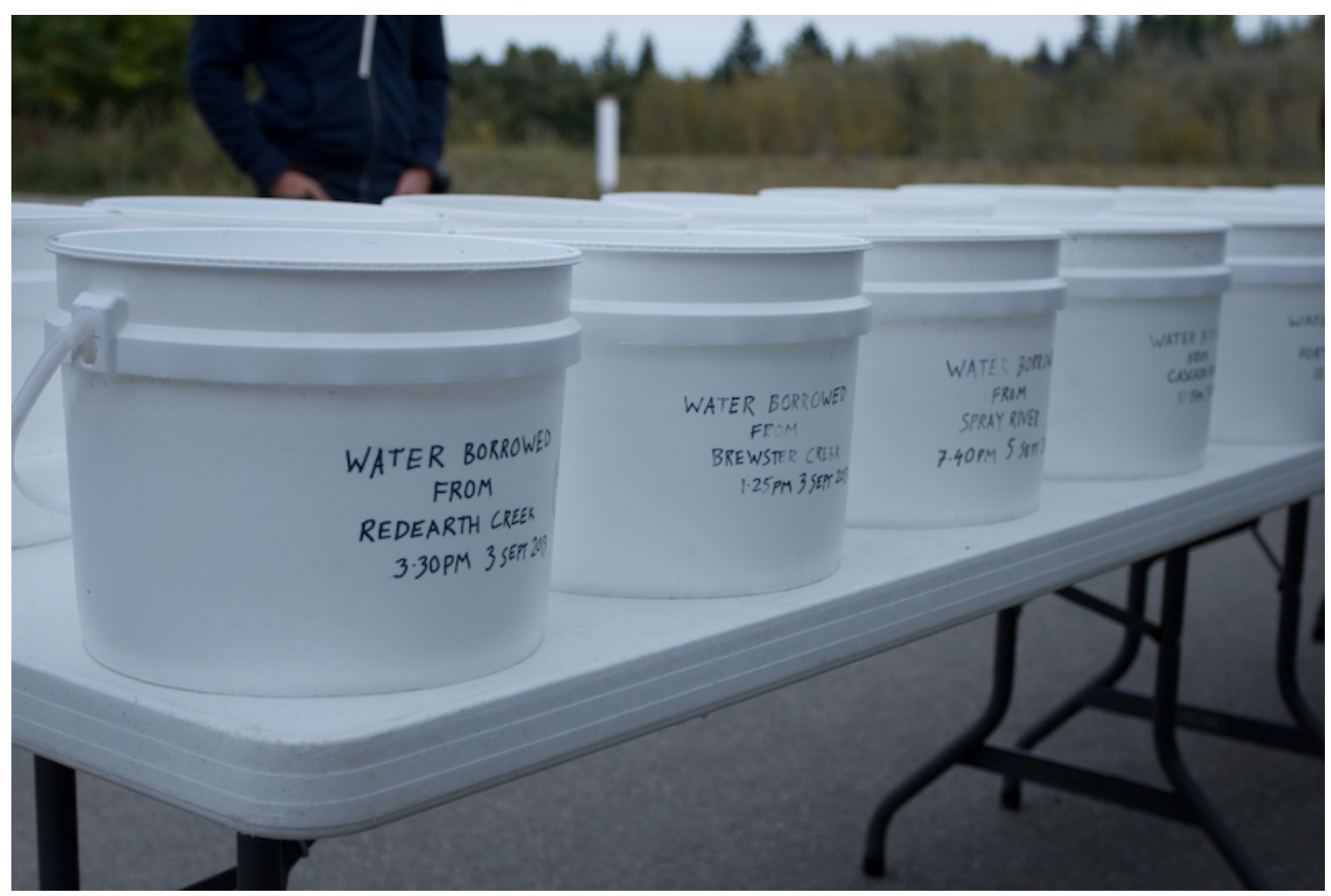

Pails of water borrowed from Bow River tributaries, Calgary

Photo: Jeremy Pavka

We placed a lid on each pail and marked on it the location, date, and time of our water borrowing.

We took the buckets of borrowed water back to Calgary. 


\section{Experiment \#3: Mix Your Own Bow}

Using data from Environment Alberta and Environment Canada, estimate how much water each tributary visited might contribute to the Bow River at Calgary, as a percentage. Using a water dropper and specially calibrated measuring equipment, take an amount of water corresponding to each percentage from the pails containing water borrowed from the Bow River tributaries. Mix these in a labelled sample bottle. Top up the mixture to $100 \%$ with water borrowed from the Bow River. Return the mixed water from the sample bottle to the Bow River.

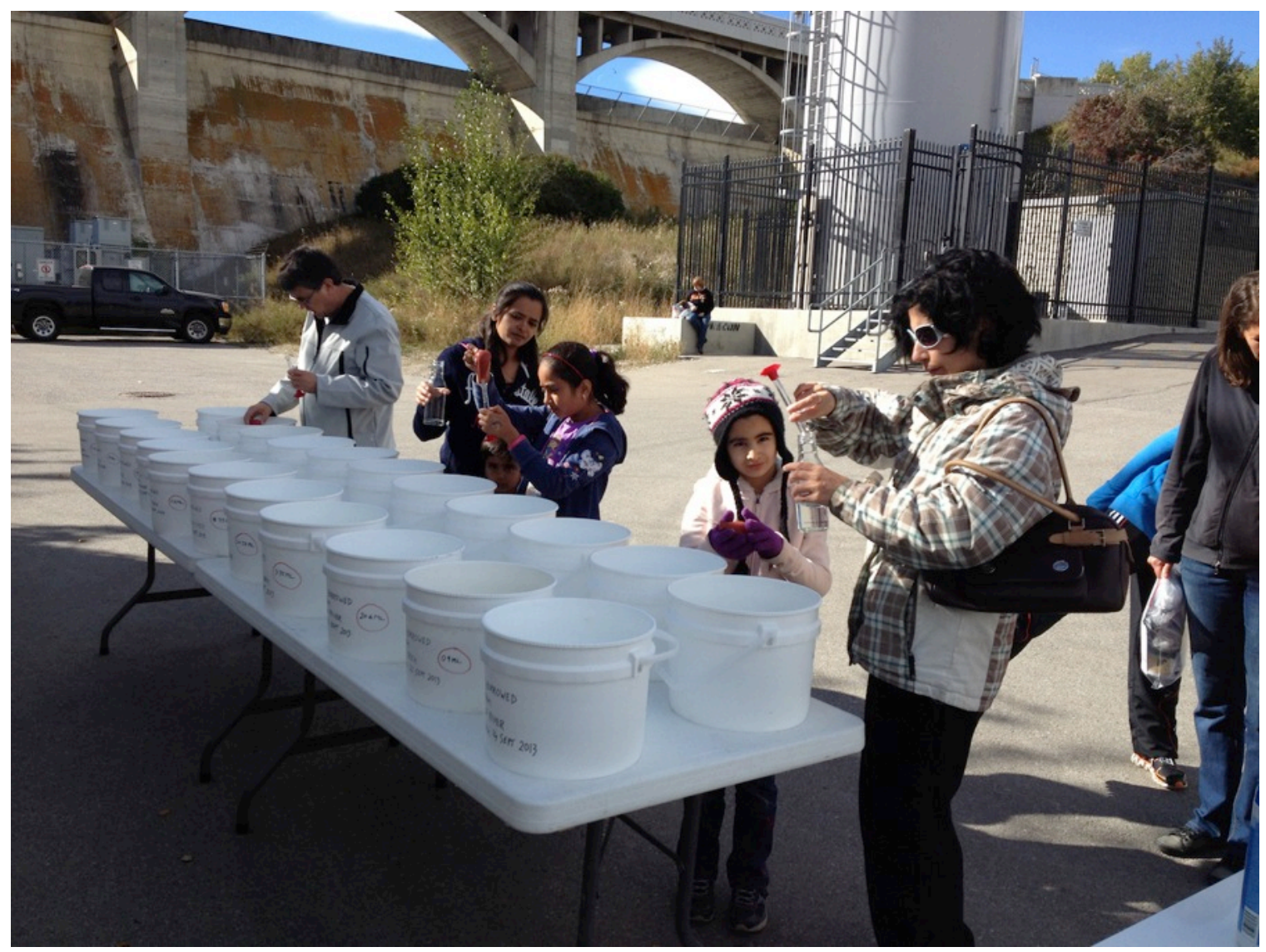

Visitors to Glenmore Dam, Calgary, Mixing their Own Bow

Photo: Jeremy Pavka

We invited people to concoct a bottle of Bow River mixture - to take samples from each pail of tributary water in the proportion that each river or creek contributes to the Bow River in Calgary and to mix it in a specially labelled bottle.

We noticed the care that people took to measure, sample, and mix the water and their intent focus on the task. 


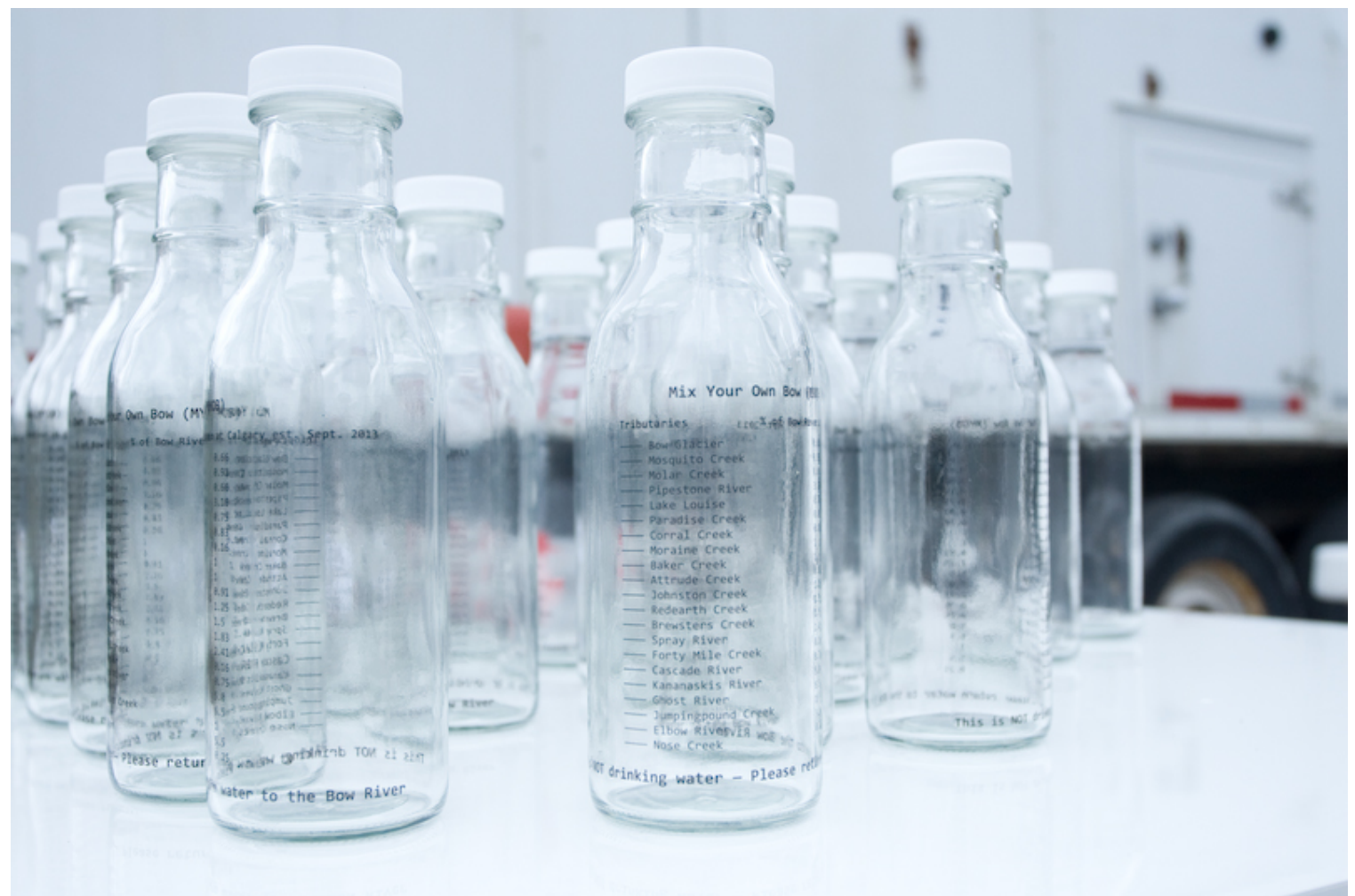

Bottles with labels detailing the proportion of water each tributary contributes to the Bow River in Calgary Photo: Jeremy Pavka

We spoke to many of the visitors about their relationship with the Bow River and its watershed.

We discovered the richness and range of people's connections with their local river and watershed.

We realised how curious and thoughtful many of them were about the role of water in their lives. 


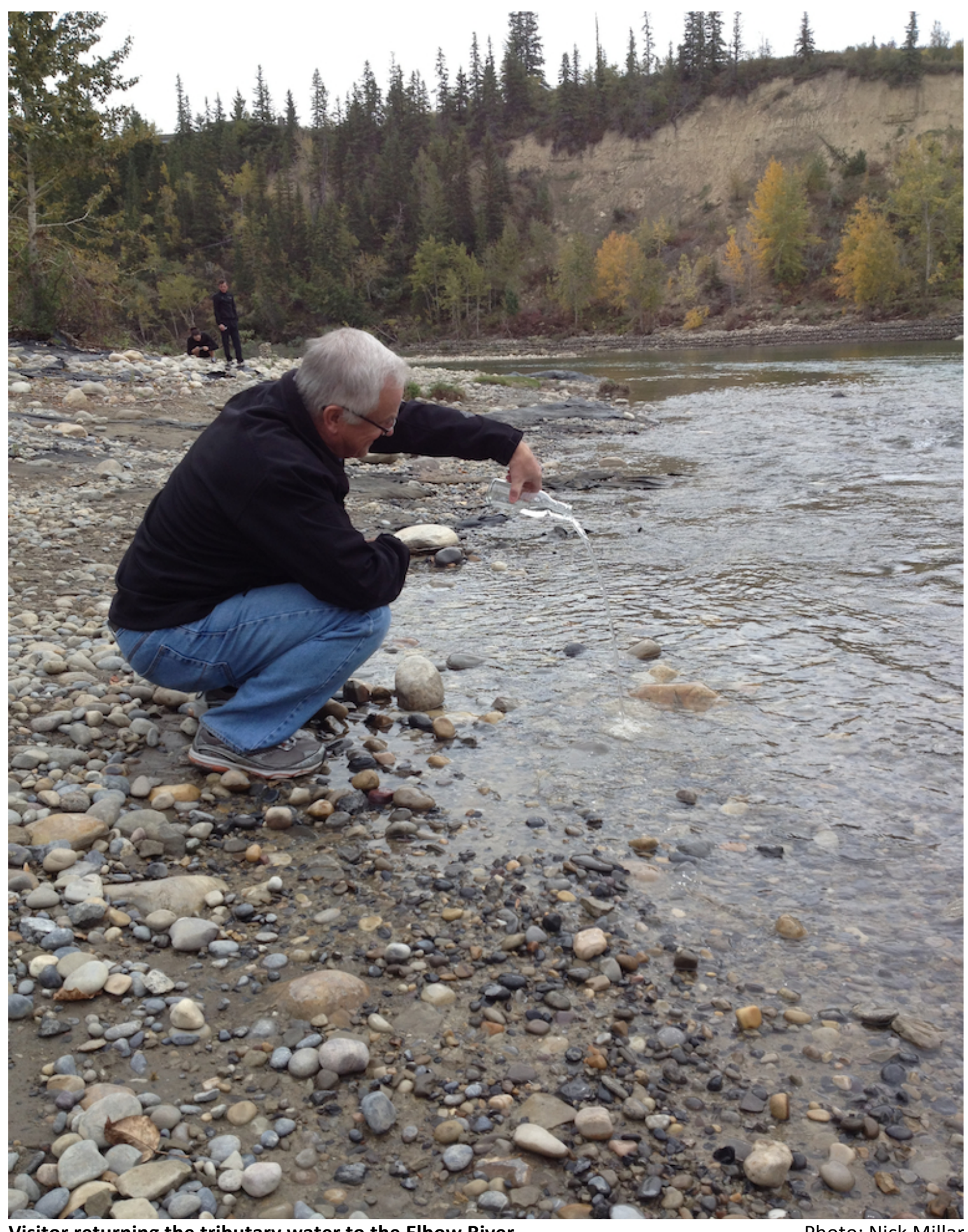

We asked them to return the water they had mixed to the Bow River watershed. 


\section{Experiment \#4: Where Water Goes (Puddles)}

Borrow a small jar of water from the river. (Remember to ask for permission and to thank the river.) Find a place where there is a crack or indentation in the road, path, or sidewalk. Pour a small amount of water into the crack or indentation. Observe where the water goes. Try this action/experiment on different types of surface, at different times of day and in different weather conditions.
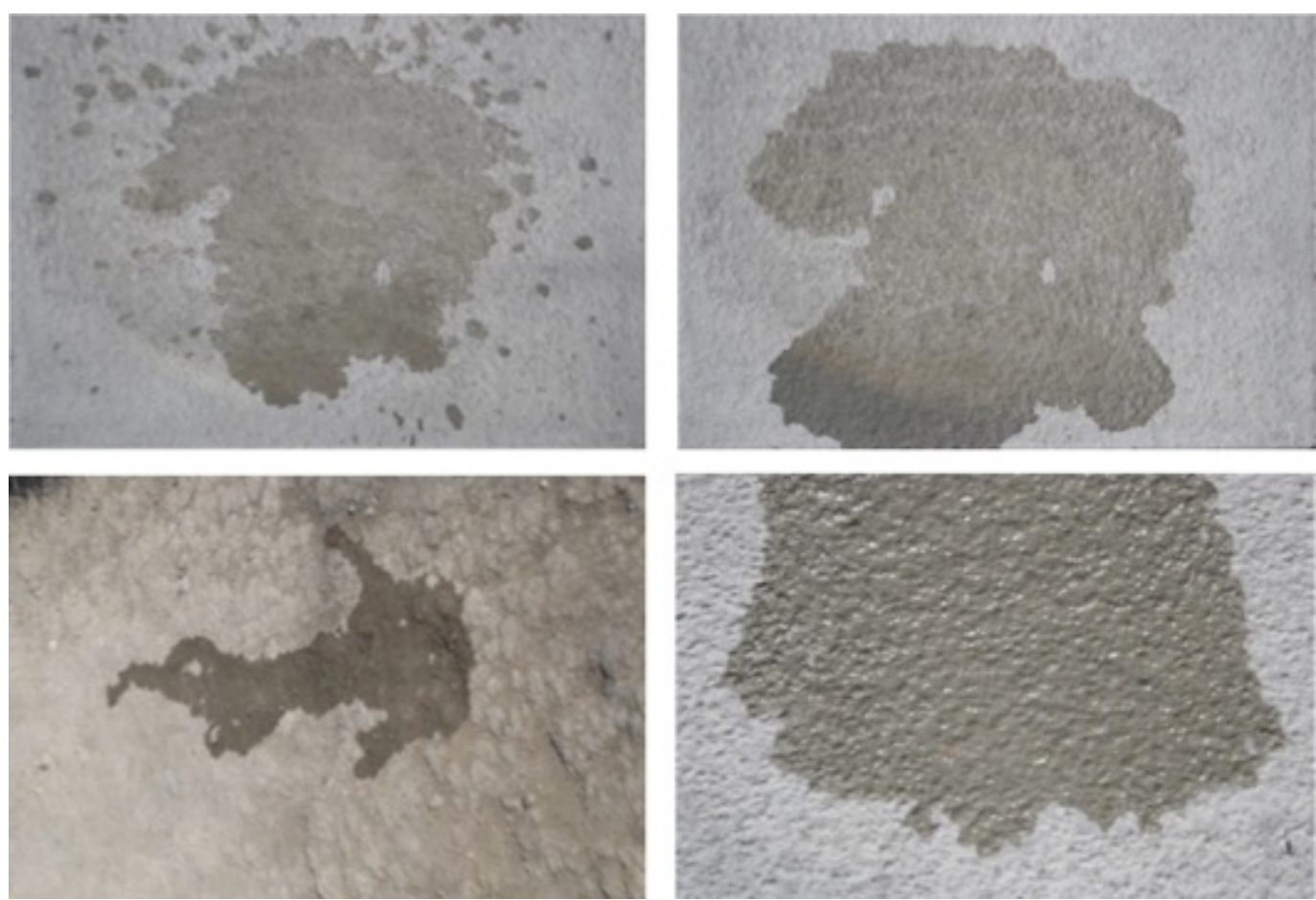

Water puddles on various surfaces, Calgary

Photos: Nick Millar

We noticed how the water puddle spread and expanded, before contracting and evaporating.

We enjoyed the shapes and patterns the water made.

We thought that the shapes looked a little like the outline of a country or state drawn on a map.

We thought about how the water might behave in different ways on more or less porous surfaces.

We thought about the consequences of covering the earth with tarmac or concrete, and how that affects where water goes.

And we thought about the floods that had submerged downtown Calgary in June 2013, moving rapidly through the built-up areas near the river. 
We thought about how the water might behave in different, less arid conditions, like the consistently damp climate of Glasgow.

We thought about how long we might have to watch a puddle there, in Scotland, until it disappeared from sight.

\section{Concluding Thoughts}

The seemingly simple experiments or actions that we carried out in Canada encouraged us, and others, to experience and understand aspects of our relationship with water in direct and profound ways - engaging our senses, intellects, emotions, and imaginations. The experiments helped us to attend to the particular geographical, cultural, and climatic conditions in Southern Alberta, and to the specific types of human/water relationships that occur there, while, at the same time, encouraging us to think about water in more universal and fundamental terms. We are intrigued to discover how the experiments will unfold in central Glasgow. For instance, the prospect of scooping up and carrying the murky, polluted water of the Clyde, which bears little resemblance to the inviting water of the blue-green Bow in Calgary, is not an appealing one. The steep, stone, quay walls of the Clyde provide very few places where the river can be accessed, unlike the gently sloping banks and shores of much of the Bow. The Clyde remains closely linked to its industrial heritage, in both its physical form and in the city's cultural memory. How might our experiments challenge or shift that perspective and suggest a new role for the river in the city?

Finally, the experiments highlighted the paradox of our (human) relationship with water and, indeed, with other more-than-human entities. We may have created situations where water could perform alongside us, and where it could determine some of the parameters of the action (for example, dictating the length of each Water Carry), but we were the ones who conceived and initiated each action, and chose where and when it took place. The experiments may have attempted to acknowledge and respect the life-force of the more-than-human (for instance, in our asking the river for permission to borrow some if its water), but our request was made in human language, and received no reply that was comprehensible to us. The experiments, and our reflections on them, made evident the impossibility of escaping our human-centric perspective - the impossibility of ever 
understanding the liveliness of more-than human entities, such as water and rivers. But they also functioned, we believe, as inspirational, speculative gestures that signalled the importance of striving for a deeper connection with the unknowable but essential and omnipresent phenomenon of water. In conclusion, we would like to extend an invitation to try out the experiments with any river around which human settlement has evolved. We invite you to guddle about.

Further information and documentation of Guddling About: Calgary can be found at www.guddling.tumblr.com www.tumblr.guddlingaboutexperiments.com

\section{Works cited}

Bennett, Jane. Vibrant Matter: A Political Ecology of Things. Durham: Duke UP, 2010. Print. Watershed+Residencies at Ralph Klein Park. The City of Calgary. No date. http://www.watershedplus.ca/residency/res-call01.pdf.

MINTY DONALD is an artist and Lecturer in Contemporary Performance Practice at the University of Glasgow, Scotland. The focus of her current practice, working in collaboration with artist Nick Millar, is on human/water interrelations. Recent and forthcoming projects include performances: Bridging Part 1 (Glasgow, Scotland, 2010); High-Slack-Low-SlackHigh (Glasgow, Scotland, 2012); Guddling About: Calgary (Calgary, Alberta, 2013), and Guddling About: Glasgow (2014); articles in Contemporary Theatre Review and Performance Research; an essay, "Entided, Enwatered, Enwinded," in Performing Objects and Theatrical Things, edited by Marlis Schweitzer and Joanne Zerdy (Palgrave, 2014), and a co-authored book, Performing Landscapes: Rivers, with Stephen Bottoms. 